\title{
Altı-12 Aylık Bebeklerin Beslenme ve Büyüme-Gelişme Durumlarının Değerlendirilmesi
}

\section{Evaluation of The Growth-Development and Nutrition Status of 6-12-Months Old Infants}

\section{Zeynep Altınbaş ${ }^{1}$ (D), Hilal Hızlı Güldemir² (D), Muazzez Garipağaoğlu³ (i)}

\author{
${ }^{1}$ istanbul Medipol Üniversitesi, İstanbul, Türkiye \\ ${ }^{2}$ Kütahya Sağlık Bilimleri Üniversitesi, Sağılık Bilimleri Fakültesi, Beslenme ve Diyetetik, Kütahya, Türkiye \\ ${ }^{3}$ Fenerbahçe Üniversitesi, Sağlık Bilimleri Fakültesi, İstanbul, Türkiye
}

ORCID ID: Z.A. 0000-0002-0560-1951; H.H.G. 0000-0002-3951-5023; M.G. 0000-0003-2172-1467

Attf/Citation: Altinbas Z, Hizli Guldemir H, Garipagaoglu M. Alth-12 aylık bebeklerin beslenme ve büyüme-gelişme durumlarının değerlendirilmesi. Çocuk Dergisi - Journal of Child 2020;20(1):13-19. https://doi.org/10.26650/jchild.2020.1.0003

öz

Amaç: Çalışma 6-12 aylık bebeklerin beslenme ve büyüme durumunu değerlendirmek amacıyla yapılmıştır.

Gereç ve Yöntem: Çalışmaya İstanbul ili, Çekmeköy ilçesinde Haziran-Eylül 2014 tarihleri arasında izlenen 300 anne-bebek çifti alınmıştır. Demografik veriler bir anket formu ile alınmış, bebeklerin bir günlük besin tüketimleri kaydedilmiş, ağırlık ve boy uzunlukları hemşireler tarafından ölçülmüştür. Bebeklerin ağılık ve boy uzunlukları ise ülkemiz için geliştirilmiş büyüme eğrileri ve $Z$ skoru ile, günlük enerji ve besin ögeleri alımları TÜBER'e göre değerlendirilmiştir.

Bulgular: Bebeklerin yüzde $45,3^{\prime}$ ü kız ve yaş ortalaması $10,1 \pm 1,9$ ay idi. Bebeklerin doğum ağırlık ve boyları ise sırasıyla $3,2 \pm 0,4 \mathrm{~kg}$ ve $49,8 \pm 2,4 \mathrm{~cm}$ iken, vücut ağılı̆̆ı, boy uzunluğu ve BKi'leri sırasıyla: $9,3 \pm 1,5 \mathrm{~kg}, 72,4 \pm 5,9$ $\mathrm{cm}, 0,73 \pm 2,24$ olarak saptanmıştır. Doğum ağırlı̆ı, boy uzunluğu ve BKi Z skoru $-1,+1$ SD olan bebeklerin oranları sırasılya: $\% 69,0, \% 47,4$ ve $\% 52,9$ iken, mevcut durumda $\% 59,1, \% 44,9, \% 42,4$ olarak bulunmuştur. Bebeklerin doğumdan sonraki süreçte vücut ağırlığı ve BKi'lerindeki artışın istatistiksel olarak anlamlı olduğu bulunmuştur $(p>0,05)$. Tüm grupta bebeklerin $\% 76,3$ 'ünün anne sütüne devam ettiği belirlenmiştir. Annelerin ilk tamamlayıcı besin olarak yoğurdu $(\% 33,1)$ tercih ettikleri, bunu muhallebi $(\% 15,7)$ ve meyve püresinin $(\% 13,4)$ izlediği gözlenmiştir. Yoğurt, sebze-meyve, yumurta, et ve tavuğun başlama zamanının sırasıyla: $24,7 \pm 4,6,24,9 \pm 5,3$, $26,6 \pm 6,1,29,6 \pm 8,3$ hafta olduğu saptanmıştır. Bebeklerin günlük beslenmeleriyle enerjiyi $971 \pm 274 \mathrm{kcal}$, proteini $27,8 \pm 12,0 \mathrm{~g}$, demir dışındaki tüm enerji ve besin ögelerini yeterli hatta fazla aldıkları görülmüştür.

Tartışma: 6-12 ay dönemindeki bebeklerin enerji dahil, pek çok besin ögesini fazla tükettikleri, doğumla karşılaştıııldığında BKi'lerinin yüksek olduğu gözlenmiştir.

Sonuç: Annelerin tamamlayıcı beslenme ve büyüme gelişme konusunda bilinçlendirilmesinin yararlı olacağı düşünülmüştür.

Anahtar Kelimeler: Anne sütü, bebek beslenmesi, büyüme, tamamlayııı beslenme
ABSTRACT

Objective: This study was planned to evaluate the growth-development and nutritional status of infants aged 6-12 months

Methods: The study included 300 mother-infant pairs in Çekmeköy, Istanbul, between June and September 2014. Information on 300 babies and their families who participated in the study were taken by a questionnaire, one-day nutritional expenditures of the babies were recorded, and weight and height lengths were measured by nurses. The weight and height of infants were evaluated according to a $Z$ score and growth curves for our country; energy and nutrient intake were evaluated with TUBER.

Results: Of the infants, $45.3 \%$ were female, and their average age was $10.1 \pm 1.9$ months. The weight and height of infants at birth were $3.2 \pm 0.4$ $\mathrm{kg}, 49.8 \pm 2.4 \mathrm{~cm}$ and current weight and height were from $9.3 \pm 1.5 \mathrm{~kg}$ and $72.4 \pm 5.9 \mathrm{~cm}$, respectively. Body weight, height and BMI ratios of infants with -1 and +1 SD $Z$ scores at birth were $69.0 \%, 47.4 \%, 52.9 \%$ and current values were $59.1 \%, 44.9 \%$ and $42.4 \%$ respectively. The increase in body weight and BMI were found to be statistically significant ( $p>0.05)$. It was observed that mothers preferred yogurt (33.1\%), pudding (15.7\%), fruit puree $(13.4 \%)$, baby biscuits $(8.4 \%)$ and eggs $(6.7 \%)$ as the first complementary foods. It was determined that yogurt was started at week

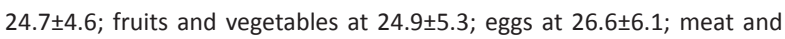
poultry at week $29.6 \pm 8$.3. It was observed that infants received $970.6 \pm 274.3$ $\mathrm{kcal} /$ day of energy and $27.8 \pm 12.0 \mathrm{~g} /$ day of protein. All energy and nutrients except iron were consumed well enough an even more.

Discussion: The study showed that 6-12 month babies overconsume many nutrients including daily energy and BMIs were found to be higher when compared with their birth.

Conclusions: It was considered beneficial to inform the mothers on the growth and development of their infants and especially on complementary nutrition.

Keywords: Infant feeding, breastfeeding, growth, complementary food

Sorumlu Yazar/Corresponding Author: Zeynep Altınbaş E-mail: zepaltinbas@gmail.com

Başvuru/Submitted: 27.05.2019 • Revizyon Talebi/Revision Requested: 26.08.2019 • Son Revizyon/Last Revision Received: 04.09.2019 • Kabul/Accepted: 23.09.2019 


\section{GíRiş}

Intrauterin dönemden başlayarak ilk iki yaştaki beslenme, hem bebek hem de yetişkin sağlığı açısından hayati önem taşır. Bu dönemdeki yetersiz beslenmenin geriye dönüşü olmayan fiziksel ve bilişsel olumsuzluklara yol açthğı bildirilmektedir (1-6). Dünya Sağlık Örgütü, bebeklerin ilk 6 ay, tek başına anne sütü ile beslenmelerini, altınc aydan itibaren tamamlayıc besinler ile birlikte emzirmenin 2 yaş ve sonrasına kadar devam ettirilmesini önermektedir $(7,8)$.

Ülkemizde anne sütü ile beslenme davranışı oldukça yaygındır. Sıfir-12 aylık bebeklerin \%99,4'ü, 13-23 aylık bebeklerin \%97,3'ü anne sütü almaktadır (9). Türkiye Nüfus ve Sağlık Araştırmaları (TNSA) 2008'e göre 6 ay süre ile sadece anne sütü verilme oranı \%40,4 iken; bu oran 2013 yılında \%30’a düşmüştür $(10,11)$. Dünyada ise ilk 6 ay sadece anne sütü verilme oranı \%38'dir. 2025 yılında \%50’nin üzerine çıkarılması amaçlanmaktadır (12).

Tamamlayıcı beslenme uygulamalarına ilişkin birçok öneri yapılmasına karşın dünya genelinde standart bir uygulamanın olmadığı bilinmektedir. Daha ötesi birçok hatalı uygulama yapılmaktadır $(5,13)$. Örneğin tamamlayıcı besinlere erken başlanması, aynı anda ya da sık aralıklarla başlanması, miktarının bebeğe özgü olmaması, 12 aydan önce inek sütü verilmesi ve bebeklerin besinlerine şeker-tuz eklenmesi, gerekmediği halde blender kullanılması hatalı yaklaşımlardan birkaçıdır $(12,14)$. Türkiye Beslenme ve Sağlık Araştırmaları'na göre, ilk bir yılda bebeklerin \%54,6'sına inek sütü verildiği saptanmıştır (9).

Tamamlayıcı besinlerin yetersiz ve dengesiz olması, büyümede aksamalara, miktarca fazla ve proteinden yüksek olması da obeziteye neden olmaktadır $(4,15,16)$. Yapılan literatür taramasında, ülkemizde bebeklik döneminde beslenme durumu ve annelerin beslenme uygulamalarına ilişkin bir çok çalışma yapılmasına karşın; tamamlayıcı beslenme uygulamaları ile büyümenin birlikte değerlendirildiği az sayıda araştırmaya rastlanmıştır $(2,17,21,22)$. Bu nedenle bu çalışma 6-12 aylık bebeklerin beslenme ve büyümelerini değerlendirmek amacıyla yapılmıştır.

\section{GEREÇ VE YÖNTEMLER}

Çalışma 15 Temmuz-15 Ekim 2014 tarihleri arasında T.C. Sağlık Bakanlığı, İstanbul Halk Sağlığı Müdürlüğü, Çekmeköy ilçesinde izlenen 6-12 ay arası 300 bebek ve anneleri ile gerçekleştirildi. Etik Kurul Onayı, Zeynep Kamil Kadın ve Çocuk Hastalıkları Eğitim Ve Araştırma Hastanesi Klinik Araştırmalar Etik Kurulundan 63 karar numara ile 18.04.2014 tarihinde alındı. Çalışmaya prematüre, düşük doğum ağırlıklı, ikiz bebek kronik hastalıklı ya da verilerin toplandığı dönemde akut hastalığı olan bebekler dahil edilmedi.

Yapılan literatür taramasından yararlanılarak bir anket formu hazırlandı. Anket formu yüz yüze görüşme tekniği ile araştırıcı tarafindan uygulandı. Araştırmaya başlamadan önce anneler araştırma hakkında sözlü olarak bilgilendirildi ve yazılı aydınlatılmış onam formu alındı. Anketin 1. bölümünde anne, aile ve bebeğe ilişkin sosyo-demografik bilgilere yer verildi. Bu kapsamda annenin doğum tarihi, eğitim durumu, ailenin gelir düzeyi ve ailedeki çocuk sayısı, bebeğin doğum tarihi, cinsiyetine ilişkin bilgi elde edildi. Doğum boyu ve ağırlığı kaydedildi. Anketin 2. bölümünde bebek beslenmesine ilişkin bilgilere yer verildi. Bu kapsamda bebeklerin tek başına ne kadar süre anne sütü ile beslendikleri, halen anne sütü ile beslenmeye devam edip etmedikleri, tamamlayıcı besinlere ne zaman başlandığı, ilk hangi tamamlayıcı besinin tercih edildiği, annelerin bebek beslenmesine ilişkin eğitim alıp almadıklarına ilişkin sorular yöneltildi.

Bebeklerin günlük enerji ve besin ögeleri alımları "Besin Tüketim Formu" ile belirlendi. Görüşme sırasında, geriye dönük (recall) olarak son 24 saatte tükettikleri tüm besinler detaylı bir şekilde sorgulanarak kaydedildi. Tüketilen besinlerin tür ve miktarlarının doğru hatırlanabilmesi için annelere çay bardağı, su bardağı, yemek kaşığı, tatlı kaşığı, çay kaşığı, servis kaşığı, kase, kepçe ve biberon gibi porsiyon ölçüleri ve gramaj tanımları, pişirme yöntemlerine ilişkin bilgiler verildi. Ayrıca yemeklerin, ekmeğin, içeceklerin, muhallebinin çeşitleri ayrıntılı bir şekilde öğrenildi. Bebeklerin günlük aldıkları enerji ve besin ögeleri tüketimlerini belirlemek için Beslenme Bilgi Sistemi (Bebis) 7,2 bilgisayar yazılım programı kullanıldı. Elde edilen değerler, Türkiye'ye Özgü Beslenme Rehberi'nde (2016) önerilen değerlerle karşılaştırıldı. Enerji besin öğelerinin yeterliliğini değerlendirmede \%66'nın alt yetersiz, \%66-133 yeterli, \%133'ün üzeri ise fazla alım olarak kabul edildi (15).

Bebeklerin mevcut vücut ağırlıkları ile boy uzunlukları deneyimli hemşireler tarafindan ölçüldü. Vücut ağırlıkları bebekler tamamen çıplak olarak 10 grama hassas dijital bebek terazisinde alındı. Boy uzunluğu ölçümleri bir kenarında mezür olan hareketli bir bölümü bulunan bir masada, yatar pozisyonda yapıldı ve anket formuna kaydedildi. Bebeklerin boya uyan ağırlıkları beden kütle indeksi (BKi): Ağırlık (kg)/boy uzunluğu $(\mathrm{m})^{2}$ formülü ile hesaplandı. Çocukların vücut ağırlığı, boy uzunluğu ve $B K I^{\prime}$ lerinin değerlendirilmesinde, $Z$ skoru kullanıldı ve \pm 1 SD standart sapma aralığı normal kabul edildi.

\section{İstatiksel yöntem}

Araştırma sonucunda elde edilen verilerin değerlendirilmesi, Windows ortamında SPSS 22 istatistiksel paket programı kullanılarak yapıldı. Uygulanan anket formunda niteliksel veriler, sayı $(n)$ ve yüzde (\%) olarak değerlendirildi. Elde edilen verilerin standart sapma (SS) ve medyanı (ort) bulundu. Sürekli veriler; ortalama, standart sapma, ortanca, alt ve üst değerler ile tanımlanırken, kesikli veriler sıklık ve yüzde dağılımı şeklinde belirtildi. İki grup karşılaştırmasında Ki kare $\left(\mathrm{X}^{2}\right)$ testi kullanıldı. Üç ve daha fazla grup karşılaştırmaları normal dağılım gösteren değişkenlerde Tek Yönlü Varyans Analizi ve sonrası ikili karşılaştırmalarında Bonferroni -Tamhane's T2 testi ve McNemar-Bowker Testi kullanılarak yapıldı. Değişkenler arasındaki ilişkilerin incelenmesinde Pearson korelasyon testi ve Spearman korelasyon testi kullanıldı. İstatiksel karşılaştırmalarda $p<0,05$ değeri anlamlı kabul edildi.

\section{BULGULAR}

Bebek ve annelere ilişkin demografik veriler Tablo 1'de verilmiştir. Yaş ortalaması 29,2 $\pm 5,6$ yıl olan annelerin $\% 28,72$ 'sinin ilköğretim, $\% 51$ 'inin ortaokul-lise, $\% 16,7^{\prime}$ 'sinin de lisans-lisansüstü 
düzeyde eğitimli oldukları belirlenmiştir. Ailelerin çoğunluğunun $(\% 67,5)$ aylık gelirinin 2000 TL'nin altında olduğu saptanmıştır. Annelerin doğum şekli olarak sezaryen doğumu (\%55), doğum yeri olarak özel hastaneyi (\%58) tercih ettikleri gözlenmiştir.

Yarıdan fazlası $(\% 54,7)$ erkek olan bebeklerin, doğum ağırlıkları ve boy uzunlukları sırasıyla: kızlarda $3,18 \pm 0,4 \mathrm{~kg}, 49,50 \pm 2,34$ $\mathrm{cm}$, erkeklerde $3,25 \pm 0,5 \mathrm{~kg}, 50,10 \pm 2,5 \mathrm{~cm}$, mevcut ağırlıkları ve boy uzunlukları ise sırasıyla: kızlarda $9,13 \pm 1,40 \mathrm{~kg}, 72,70 \pm 5,50$ $\mathrm{cm}$, erkeklerde $9,53 \pm 1,58 \mathrm{~kg}, 72,32 \pm 6,24 \mathrm{~cm}$ olarak bulunmuştur. Bebeklerin doğumdaki tartı ve boyları Tablo 1'de verilmiştir (Tablo 1).

Bebeklerin +1 ve -1 SD arasındaki doğum ağırlığı, boy uzunluğu ve BKi'lerinin sırasıyla: $\% 69, \% 47,4$ ve $\% 52,9$ olduğu, mevcut ağılık, boy uzunluğu ve BKi'lerinin ise sırasıyla: $\% 59,1, \% 44,9$ ve $\% 42,4$ olduğu belirlenmiştir. Doğumda vücut ağırlığı ve BKi'si +1 ve üstü SD olan bebeklerin oranı sırasıyla: $\% 10,4, \% 16,4$ iken; mevcut durumda bu oranların sırasıyla: $\% 24,2$ ve $\% 39,4$ olduğu gözlenmiştir (Tablo 2).

Tablo 3'de tamamlayıcı besinlere başlama zamanı görülmektedir. Annelerin ilk tamamlayıcı besin olarak $24,7 \pm 4,6$ haftada yoğurdu tercih ettikleri, bunu $24,9 \pm 5,2$ haftada sebze-meyve püresinin, 25,0 $\pm 6,8$ haftada muhallebinin izlediği, yumurtanın $26,6 \pm 6,1$ haftada, kırmızı etin ise $29,6 \pm 8,3$ haftada başlandığı saptanmıştir.

Günlük beslenmede bebeklerin en fazla süt grubundaki besinlerden anne sütü, formüla, inek sütü - yoğurdu sırasıyla: $352 \pm 273 \mathrm{ml}, 74 \pm 166 \mathrm{ml}, 221 \pm 62 \mathrm{ml}$ miktarlarında tükettikleri

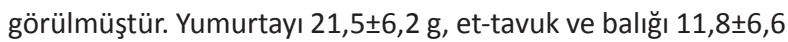
g, ekmek ve diğer tahılları 53,1 $\pm 10,7 \mathrm{~g}$, sebzeyi $45,4 \pm 5,5 \mathrm{~g}$, meyveyi 105,2 $\pm 14,7 \mathrm{~g}$ tükettikleri bulunmuştur. Genel olarak şekerden uzak durdukları şeker, reçel ve balı 1 tatlı kaşığından az, yağı ise 2 tatı kaşığına yakın miktarda tükettikleri belirlendi.

Şekil 1'de bebeklerin günlük enerji ve besin ögeleri alımların (yetersiz, yeterli ve fazla olarak) gereksinimlerini karşılama dağılımları gösterilmiştir. Tüm bebeklerin enerjiyi normal düzeyde veya fazla aldıkları belirlenmiştir. Makro besin ögelerinden protein ve yağın bebeklerin çoğunluğu tarafindan fazla, karbonhidratın ise normal düzeyde alındığı saptanmıştır. Bebekler arasında demir hariç hemen tüm vitamin ve minerallerin fazla tüketildiği, demirin bebeklerin $\% 73,6$ 'sı tarafindan yetersiz tüketildiği gözlenmiştir.

\section{TARTIŞMA}

Bebeğin erişkin tipi beslenmeye hazırlandığı bu dönemde yeterli ve dengeli beslenmenin sağlanabilmesi için; annenin yaşının, eğitim düzeyi, sosyoekonomik durumu ve ailedeki çocuk sayısı gibi sosyo-demografik özelliklerinin uygun olması gerekir. Türkiye Nüfus ve Sağlık Araştırmaları (TNSA) 2013 verilerine göre ülke genelindeki kadınların eğitim düzeyi 7,3 yıl olarak bulunmuştur (16). Yaş ortalaması 29,1 $\pm 5,6$ yıl olan annelerimizin ise $\% 43,7$ 'sinin lise ve üzerinde eğitimli olduğu görülmüştür. Çalışmaya katılan annelerin eğitim düzeyinin, ülkemiz ortalamasının üzerinde olduğu belirlenmiştir. Türkiye genelinde sezaryen
Tablo 1: Bebek ve annelere ilişkin demografik veriler

\begin{tabular}{|c|c|c|}
\hline \multirow{2}{*}{ Özellik } & \multicolumn{2}{|c|}{ Toplam } \\
\hline & $\mathbf{n}$ & $\%$ \\
\hline \multicolumn{3}{|l|}{ Bebekler } \\
\hline \multicolumn{3}{|l|}{ Cinsiyet } \\
\hline Kız & 136 & 45,3 \\
\hline Erkek & 164 & 54,7 \\
\hline Toplam & 300 & 100,0 \\
\hline Yaş (ay) (OrtıSS) & \multicolumn{2}{|c|}{$10,12 \pm 1,9(n=300)$} \\
\hline \multicolumn{3}{|l|}{ Doğumda (Ort士SS) } \\
\hline Vücut ağırlığı (g) & \multicolumn{2}{|c|}{$3,22 \pm 0,4(n=297)$} \\
\hline Boy uzunluğu (cm) & \multicolumn{2}{|c|}{$49,83 \pm 2,4(n=274)$} \\
\hline \multicolumn{3}{|l|}{ Mevcut (Ort $\pm S S$ ) } \\
\hline Vücut ağırlığı (g) & \multicolumn{2}{|c|}{$9,35 \pm 1,51(n=283)$} \\
\hline Boy uzunluğu (cm) & \multicolumn{2}{|c|}{$72,49 \pm 5,92(n=234)$} \\
\hline \multicolumn{3}{|l|}{ Anne sütüne başlama zamanı (saat) } \\
\hline $0-1$ & 228 & 76,0 \\
\hline $2-4$ & 35 & 11,7 \\
\hline $5-24$ & 9 & 3,3 \\
\hline $25 \geq$ & 27 & 9,0 \\
\hline Anne sütüne başlama zamanı (saat) (Ort $\pm S S$ ) & \multicolumn{2}{|c|}{$5,99 \pm 13,8(n=300)$} \\
\hline \multicolumn{3}{|l|}{ Tek başına anne sütü ile beslenme (hafta) } \\
\hline $1-4$ & 251 & 83,6 \\
\hline $5-17$ & 157 & 52,4 \\
\hline $18-26$ & 22 & 7,3 \\
\hline $27 \geq$ & 7 & 2,3 \\
\hline 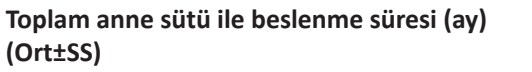 & \multicolumn{2}{|c|}{$8,21 \pm 2,86(n=300)$} \\
\hline
\end{tabular}

\begin{tabular}{|c|c|c|}
\hline \multicolumn{3}{|c|}{ Anneler } \\
\hline Yaş (yıl) (OrttsS) & \multicolumn{2}{|c|}{$29,12 \pm 5,6$} \\
\hline \multicolumn{3}{|l|}{ Eğitim durumu } \\
\hline Okur yazar değil- İlkokul & 97 & 32,4 \\
\hline Ortaokul-lise & 153 & 51,0 \\
\hline Lisans/yüksek lisans ve üzeri & 50 & 16,7 \\
\hline Toplam & 300 & 100,0 \\
\hline \multicolumn{3}{|l|}{ Ailenin aylık geliri } \\
\hline$\leq 2000 \mathrm{TL}$ & 199 & 67,5 \\
\hline $2000 \mathrm{TL} \geq$ & 96 & 32,5 \\
\hline Toplam & 295 & 100,0 \\
\hline \multicolumn{3}{|l|}{ Doğum şekli } \\
\hline Normal & 135 & 165 \\
\hline Sezaryen & 45,0 & 55,0 \\
\hline Toplam & 300 & 100,0 \\
\hline
\end{tabular}


Tablo 2: Bebeklerin doğumdaki ve mevcut durumdaki antropometrik ölçümlerinin karşılaştırılması

\begin{tabular}{|c|c|c|c|c|c|c|}
\hline \multirow{2}{*}{ Antropometrik ölçüm } & \multirow{2}{*}{ Z Skoru (SD) } & \multicolumn{2}{|c|}{ Doğum } & \multicolumn{2}{|c|}{ Mevcut } & \multirow[t]{2}{*}{$\mathbf{p}$} \\
\hline & & $\mathrm{n}$ & $\%$ & $\mathrm{n}$ & $\%$ & \\
\hline \multirow{4}{*}{ Vücut Ağırlığı (kg) } & -1 ve altı & 61 & 20,5 & 47 & 16,7 & \multirow{4}{*}{0,000} \\
\hline & -1 ve +1 & 205 & 69,0 & 166 & 59,1 & \\
\hline & +1 ve üstü & 31 & 10,4 & 68 & 24,2 & \\
\hline & Toplam & 297 & 100 & 283 & 100 & \\
\hline Vücut Ağırlığı (kg) & (Ort $\pm S S)$ & \multicolumn{2}{|c|}{$-0,17 \pm 1,10$} & \multicolumn{2}{|c|}{$0,17 \pm 1,45$} & \\
\hline \multirow{4}{*}{ Boy Uzunluğu (cm) } & -1 ve altı & 67 & 24,5 & 81 & 34,8 & \multirow{4}{*}{0,183} \\
\hline & -1 ve +1 & 130 & 47,4 & 100 & 44,9 & \\
\hline & +1 ve üstü & 77 & 28,1 & 52 & 22,3 & \\
\hline & Toplam & 274 & 100 & 234 & 100 & \\
\hline Boy Uzunluğu (cm) & (Ort $\pm S S)$ & \multicolumn{2}{|c|}{$0,18 \pm 1,36$} & \multicolumn{2}{|c|}{$-0,51 \pm 2,42$} & \\
\hline \multirow{4}{*}{ BKi $\left(\mathrm{kg} / \mathrm{m}^{2}\right)$} & -1 ve altı & 84 & 30,7 & 42 & 18,2 & \multirow{4}{*}{0,000} \\
\hline & -1 ve +1 & 145 & 52,9 & 98 & 42,4 & \\
\hline & +1 ve üstü & 45 & 16,4 & 91 & 39,4 & \\
\hline & Toplam & 274 & 100 & 232 & 100 & \\
\hline BKi $\left(\mathrm{kg} / \mathrm{m}^{2}\right)$ & (Ort $\pm S S)$ & \multicolumn{2}{|c|}{$-0,38 \pm 1,36$} & \multicolumn{2}{|c|}{$0,73 \pm 2,24$} & \\
\hline
\end{tabular}

Tablo 3: Bebeklere verilen ilk tamamlayıcı besin ve başlama haftası

\begin{tabular}{lccc}
\hline Besinler & $\mathbf{n}$ & $\%$ & Başlama Haftası \\
\hline Yoğurt & 99 & 33,1 & $24,7 \pm 4,6$ \\
Sebze- meyve püresi & 40 & 13,4 & $24,9 \pm 5,2$ \\
Muhallebi & 47 & 15,7 & $25,0 \pm 6,8$ \\
Bisküvi & 25 & 8,4 & $26,3 \pm 6,9$ \\
Yumurta & 20 & 6,7 & $26,7 \pm 6,1$ \\
Pekmez & 17 & 5,7 & $26,6 \pm 7,2$ \\
Ev yemekleri & 7 & 2,3 & $29,1 \pm 7,8$ \\
Kırmızı et & 4 & 1,3 & $29,6 \pm 8,3$ \\
İnek sütü & 2 & 0,7 & $32,9 \pm 15,1$ \\
Diğer & 38 & 12,8 & $30,9 \pm 8,3$ \\
\hline
\end{tabular}

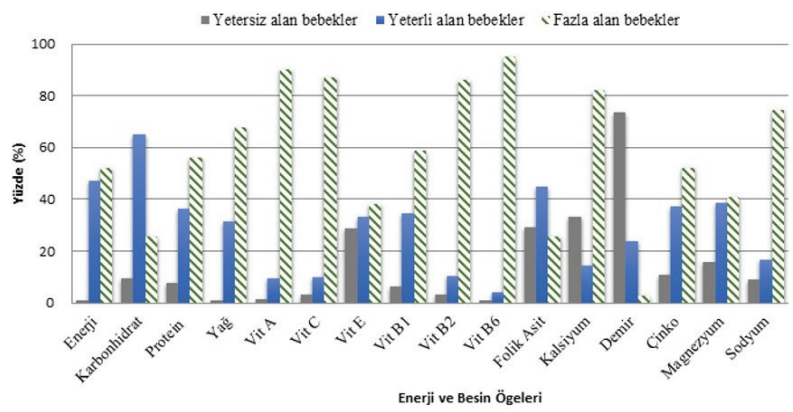

Şekil 1: Bebeklerin enerji ve besin öğeleri tüketimlerinin önerileri karşılama durumu. doğum oldukça sıktır, TNSA 2013 verilerinde doğumların yüzde $48^{\prime}$ inin sezaryen olduğu tespit edilmiştir (10). Çalışma grubumuzdaki sezaryen doğum oranı (\%55) da ülkemiz verilerine paralellik göstermektedir.

Anne sütü ile beslenme, bebeğin hayatta kalması ve sağlığının korunması için önemli bir köşe taşıdır. Dünya Sağlık Örgütü (DSÖ) 2014'te, altı aydan küçük bebeklerde tek başına anne sütü ile beslenme oranını \%38 olarak bildirilmiştir (23). Birleşmiş Milletler Çocuklara Yardım Fonu (UNICEF) verilerine göre Çin'de tek başına anne sütü ile beslenme oranı 4 aydan küçük bebekler için $\% 77$ iken, 6 . aydan küçük bebekler için \%51 olarak saptanmıştır (24). Brezilya'da 4-12 aylık 179 bebekle yapılan bir çalışmada, tek başına anne sütü alma ve tamamlayııı besinlere başlama zamanı araştırılmıştır. Ortalama 6 aylık olan bebeklerin \%50,3'ünün tek başına anne sütü ile beslenmeyi bıraktığı ve 4.aydan itibaren tamamlayıc beslenmeye başlanıldığı ortaya konulmuştur (25). Ülkemizde TNSA verilerine göre 2008'de \%40 olan ilk 6 ay tek başına anne sütü alma oranın 2013'te \%30'a düştüğü, toplam anne sütü alma süresinin ortalama 14,5 ay olduğu belirtilmiştir $(10,11,15)$. Kayseri'de yapılan bir çalışmada ise toplam anne sütü ile beslenme süresi 11 ay olarak saptanmıştır (26). Dünya ve ülkemiz verileri karşılaştırıldığında, çalışma grubumuzdaki bebeklerin ilk 6 ayda tek başına anne sütü ile beslenme oranının daha düşük, toplam anne sütü alma süresinin daha kısa olduğu belirlenmiştir. Bu durum formüla ve tamamlayıcı besinlerin erken başlanması ile açıklanmıştır.

Yaşamın ilk yılında büyümenin izlenmesi, bebeğin sağlığı ve beslenmenin yeterliliği açısından önemlidir. Bebeklerin doğum ağırlıkları ülkelere göre farklılık göstermektedir. Güney Asya'da 2003, İtalya'da 2010, Meksika'da 2012 yıllarında yapılan çalışmalarda bebeklerin doğum ağırlıkları sırasıyla 2,900 g, 3,240 g, 
2,950 g; Neyzi ve ark. (27-30) 2008 yılında ülkemiz genelinde yapmış oldukları çalışmada ise $3,360 \mathrm{~g}$ olarak bulunmuştur. ÇaIışmamızdaki bebeklerin de Caroli ve Neyzi'nin çalışmalarıyla benzer doğum ağırlığı ve boy uzunluğuna sahip olduğu görülmüştür $(29,31)$.

Altıncı ayda bebeklerin vücut ağırlıklarının doğumun 2 katına, 1 yaşında ise 3 katına çıkması beklenir (32). Aktaç ve ark. (33) İstanbul'da yaptıkları bir çalışmada bebeklerin 9. aydaki ortalama vücut ağırlığı: $9,06 \pm 1,14 \mathrm{~kg}$ ve boy uzunluğu: $72,5 \pm 2,5 \mathrm{~cm}$ bulunmuştur. Ülkemiz genelinde mevcut ağırlık ortalaması 0,4 SD, mevcut boy ortalaması 0,35 SD olarak bulunmuştur (10). Beş yaşından önce BKi'deki hızlı sıçramaların yetişkin dönem obezitesi ile ilişkili olabileceği gittikçe önem kazanmakta olan bir konudur (34). Güncel bir çalışmada 131 bebeğin BKi eğrilerindeki değişim ve bunu etkileyen faktörler incelenmiş, maternal obezite ve bebeklikte yüksek kalorili beslenmenin, ilerleyen dönemde obezite için anlamlı derecede risk faktörü olduğu ortaya konmuştur (35). Bir başka kohort çalışmasında 4744 bebek, 8 yaşına kadar izlenmiş ve BKi Z-skorlarında 6. ay, 12. ay ve 18 . aydaki artışların, ilerleyen yaşlardaki yüksek BKi Z-skor ile pozitif ilişkili olduğu ortaya konmuştur (36). Çalışmamızda da bebeklerin doğumda vücut ağırlığı ve BKI'si +1 ve üstü SD olan bebeklerin oranı sırasıyla: \%10,4, \%16,4 iken; mevcut durumda bu oranların sırasıyla: \%24,2 ve \%39,4 olduğu, bu değerlerin Ip ve Börnhorst'un çalışmalarıyla paralellik gösterdiği gözlenmiştir $(35,36)$.

Alt aylık olan bebeklere, anne sütü ile birlikte yeterli miktarda, uygun kıvamlı, güvenli, hijyenik, bebekler tarafindan kolay yenebilen-sevilen, ucuz, kolay ulaşılabilir-satın alınabilir, hazırlanması kolay tamamlayıcı besinlerin başlanması gerekir. Avrupa Pediatrik Gastroenteroloji, Hepatoloji ve Beslenme Birliği (ESPGHAN) Komitesi, bebeklerin ilk 6 ay tek başına anne sütü ile beslenmelerini ve tamamlayıcı beslenmeye 17 . haftadan erken ve 26. haftadan geç başlanılmamasını önermektedir (37). Türkiye Nüfus ve Sağlık Araştırmaları 2008 verilerine göre bebeklerin yüzde 8'i ilk 6 aylık dönemde tamamlayıcı beslenmeye başlarken; 2013'te bu oran \%12'ye yükselmiştir (10). ÇaIışmamızda ilk tamamlayıcı besine başlama zamanı $(24,7 \pm 4,6$ hafta), ESPHGAN önerileri ve TNSA 2013 verileri ile benzerlik göstermektedir $(10,37)$.

Caetano ve ark. çalışmasında, 6 . aydan küçük bebeklerde tamamlayıcı besin olarak meyve $(\% 84,6)$, sebze $(\% 63)$, kurabiye $(\% 38,5)$, et çeşitleri $(\% 33,8)$ ve işlenmiş hazır besinlerin $(\% 20)$ yer aldığı bildirilmiştir (25). Li ve ark. Amerika'daki annelerle yaptıkları bir çalışmada ise annelerin düşük eğitim düzeyi, genç yaşta doğum yapma, kısa doğum izni, yenidoğan yoğun bakım ünitelerinde biberon kullanımı ve ailelerin yağ, basit karbonhidratlar ve tuz bakımından zengin besinler verme isteğini, başta inek sütü olmak üzere, tamamlayıcı besinlere erken başlama nedenleri olarak vurgulanmıştır (38). Kayseri'de 0-36 aylık çocukların beslenme durumları değerlendirildiği bir çalışmada, ilk tamamlayıcı besin olarak inek sütü $(\% 23,4)$ başlandığı saptanmıştır. Aynı çalışmada inek sütü, yoğurt ve meyve suyunun erken başlandığı, et-tavuk-balık, peynir, tam yumurtaya ise geç başlandığı ortaya konmuştur (26). Türkiye genelinde ilk tamamlayıcı besin olarak yoğurt başlanan bebeklerin oranı \%89,0'dur (11).
Türkiye Beslenme ve Sağlık Araştırmaları 2010 verilerine göre; bebeklerin ortalama 9,9 aylıkken tavuk-hindi, 10,3 aylıkken balık ve 8,7 aylıkken yumurta sarısına başlandığı ancak 2 yaşından küçük bebeklerin sadece \%50,9'unun kırmızı et ile tanışt̆ğı tespit edilmiştir (9). Bu çalışmaların aksine, çalışma grubumuzdaki bebeklerin yumurta, kırmızı et ve tavuk ile daha erken tanıştı̆̆ ve günlük beslenmelerinde en fazla inek sütü, yoğurt, tahıllı besinler ve yumurta tükettikleri saptanmıştir.

Büyüme gelişmenin devamı ve sağlığın korunması için bebeklerin günlük enerji ve besin ögelerini, önerilen miktarlarda tüketmeleri gerekmektedir. Conn ve arkadaşlarının Avusturalya'da yaptı̆̆ı çalışmada, 9 aylık bebeklerin \%9'unda yetersiz demir alımı tespit edilmiştir (39). Butte ve arkadaşlarının Amerika'da 6-11 aylık 505 bebek ile yaptıkları çalışmada bebeklerin \%12'sinde yetersiz demir alımı bildirilmiştir (40). Çalışmamızda ise bebeklerin (\%51) demir hariç hemen tüm besin ögelerini yeterli, hatta önerilenin üzerinde tükettikleri saptanmıştr. Yetersiz demirin alımında, günlük ortalama kırmızı et tüketiminin ( $6 \mathrm{~g})$ az olmasının etkili olabileceği düşünülmektedir (Tablo 4). Boran ve Aktaç'ın 9-12 aylık 130 emzirilen bebekte besinsel çeşitlilik ve besin içeriğini araştırdıkları çalışmada, çalışmamıza paralel olarak yüksek enerji ve protein alımı tespit edilmiştir (41). Özellikle enerji, protein ve yağ alımlarının önerilerin üzerinde olmasının (\%136, \%154, \%160) bebekler ve ailelerinin besine kolay ulaşma imkanına sahip olmalarıyla ilişkili olabileceği düşünülmüştür.

Tablo 4: Bebeklerin tükettikleri günlük besin miktarları

\begin{tabular}{llc}
\hline Besin Grupları & Besinler & Ortalama \pm SS \\
\hline Süt ve Süt Ürünleri (ml/g) & Anne sütü & $352,11 \pm 272,84$ \\
& Formüla & $74,5 \pm 166,3$ \\
& İnek sütü, yoğurt & $221,0 \pm 62,5$ \\
& Peynir & $13,9 \pm 3,5$ \\
\hline Et ve Ürünleri, Yumurta (g) & Kırmızı et & $6,18 \pm 5,1$ \\
& Tavuk, balık & $5,6 \pm 1,5$ \\
& Yumurta & $21,6 \pm 6,2$ \\
& Kurubaklagil, yağlı tohum & $9,6 \pm 2,5$ \\
\hline Ekmek ve Tahıllar (g) & Ekmek & $21,5 \pm 5,7$ \\
& Tahıllar & $31,6 \pm 5,0$ \\
\hline Sebze ve Meyveler (g) & Sebzeler & $45,4 \pm 5,5$ \\
& Meyveler & $105,2 \pm 14,7$ \\
\hline Sçecekler (ml) & Şeker, bal, reçel, pekmez & $2,0 \pm 0,6$ \\
& Diğer & $1,9 \pm 0,4$ \\
\hline Yağlar (g) & içme suyu & $5,8 \pm 1,3$ \\
& Çay & $2,2 \pm 0,6$ \\
\hline & & $320,3 \pm 92,5$ \\
& & $6,4 \pm 1,3$ \\
\hline & & \\
& &
\end{tabular}




\section{SONUÇ}

Çalışmamızdaki bebeklerin bazı besinleri fazla tükettikleri ve doğumla karşılaştrıldığında vücut ağırlıklarının fazla olduğu görülmüştür. Çalışmanın kısıtlarından biri olan sosyo-ekonomik düzeyin yüksek olmasının bunda etkili olabileceği düşünülmektedir. Bebeklerin sağııkı büyüyüp gelişebilmeleri ve çocukluk obezitesinin önüne geçilebilmesi için annelerin, gebelik sürecinde emzirme ve tamamlayıc beslenme konusunda bilinçlendirilmeleri faydalı olacaktır. Bebek beslenmesi ve büyüme arasındaki ilişkinin daha ileri çalışmalarla incelenmesinin yararlı olacağı düşünülmüştür.

Etik Komite Onayı: Bu çalışma için etik komite onayı Zeynep Kamil Kadın ve Çocuk Hastalıkları Eğitim Ve Araştırma Hastanesi Klinik Araştırmalar Etik Kurulu'ndan alınmıştir.

Bilgilendirilmiş Onam: Katlımcılardan bilgilendirilmiş onam alınmıştır.

Hakem Değerlendirmesi: Dış bağımsız.

Yazar Katkıları: Çalışma Konsepti/Tasarım- M.G.; Veri Toplama- Z.A.; Veri Analizi/Yorumlama- Z.A., H.H.G., M.G.; Yazı Taslağı- Z.A.; İçeriğin Eleştirel İncelemesi- M.G.; Son Onay ve Sorumluluk- Z.A., H.H.G., M.G.; Malzeme ve Teknik Destek- H.H.G.; Süpervizyon- H.H.G., M.G.

Çıkar Çatışması: Yazarlar çıkar çatışması beyan etmemişlerdir.

Finansal Destek: Yazarlar finansal destek beyan etmemişlerdir.

Ethics Committee Approval: This study was approved by the Zeynep Kamil Women and Child Diseases Training and Research Hospital Clinical Research Ethics Committee.

Informed Consent: Written consent was obtained from the participants.

Peer Review: Externally peer-reviewed.

Author Contributions: Conception/Design of Study- M.G.; Data Acquisition- Z.A.; Data Analysis/Interpretation- Z.A., H.H.G., M.G.; Drafting Manuscript- Z.A.; Critical Revision of Manuscript- M.G.; Final Approval and Accountability- Z.A., H.H.G., M.G.; Technical or Material Support- H.H.G.; Supervision- H.H.G., M.G.

Conflict of Interest: Authors declared no conflict of interest.

Financial Disclosure: Authors declared no financial support.

\section{KAYNAKLAR/REFERENCES}

1. King C, Davis T. Nutritional treatment of infants and children with faltering growth. Eur J Clin Nutr 2010;64(1):11-3.

2. Kaya Z, Yiğit Ö, Erol M, Bostan Gayret Ö. Altt-yirmi dört ay arası yaş grubunda beslenmeyle ilgili anne ve babaların bilgi ve deneyimlerinin değerlendirilmesi. Haseki Tıp Bülteni 2016;54(2):705.

3. Köksal G, Gökmen H. Çocuk Hastalıklarında Beslenme Tedavisi. 2008. p955.
4. Akman Aşık S. Çocuklarda dengeli beslenmenin önemi. Klin Tıp Pediatr Derg 2015;7(2):12-7.

5. Hür G, Şen Celasin N. Tamamlayıcı besinler geçişin önemi ve durum değerlendirmesi. Uluslararası Aile Çocuk ve Eğitim Derg 2014;2(3):104-15.

6. Yılmazbaş P, Kural B, Uslu A, Sezer GM, Gökçay G. Annelerin gözünden ek besinlere başlama nedenleri ve annelerin mamalar hakkındaki düşünceleri. İst Tıp Fak Derg 2015;78(3):76-82.

7. Gökçay G, Garipağaoğlu M. Sağlıklı Çocuğun Beslenmesi. In: Pediyatri 2009. p. 183-94.

8. Scott MI. Feeding and nutrition of infants and young children: guidelines for the WHO European region, with emphasis on the former soviet countries. J Hum Lact 2001;17(3):265-6.

9. Sağlık Bakanlığı. Türkiye beslenme ve sağlık araştırması 2010: Beslenme durumu ve alışkanlıklarının değerlendirilmesi sonuç raporu (serial online) 2014. p. 91-504.

10. Hacettepe Üniversitesi Nüfus Etütleri Enstitüsü. Türkiye nüfus ve sağlık araştırması 2013. Hacettepe üniversitesi nüfus etütleri enstitüsü, T.C. Kalkınma Bakanlığı ve TÜBITAK, Ankara, Türkiye. 2014. p. 161.

11. Hacettepe Üniversitesi Nüfur Etütleri Enstitüsü. Türkiye nüfus ve sağlık araştırması. 2008.

12. Friel JK, Isaak C a., Hanning R, Miller A. Complementary food consumption of Canadian infants. Open Nutr J 2009;3(1):11-6.

13. Yılmazbaş $P$, Gökçay $G$. İlk iki yaşta sağlıklı beslenme ve sağlıklı beslenme alışkanlığınıngeliştirilmesi. Çocuk Dergisi 2015;13(4):14753.

14. Schwartz C, Scholtens PAMJ, Lalanne A, Weenen H, Nicklaus S. Development of healthy eating habits early in life. Review of recent evidence and selected guidelines 2011;57(3):796-807. http://dx.doi.org/10.1016/j.appet.2011.05.316

15. Hacettepe Üniversitesi Sağlık Bilimleri Fakültesi. Türkiye'ye özgü besin ve beslenme rehberi. 2015.p.97.

16. Cattaneo A, Williams C, Pallas-Alonso CR, Hernandez-Aguilar MT, Lasarte-Velillas JJ, Landa-Rivera L, et al. ESPGHAN's 2008 recommendation for early introduction of complementary foods: How good is the evidence? Matern Child Nutr 2011;7(4):335-43.

17. Onbaşi Ş, Duran R, Çiftdemir NA, Vatansever Ü, Acunaş B, Süt $N$. Doğum öncesi anne adaylarına verilen emzirme ve anne sütü eǧitiminin emzirme davranışları üzerine etkisi. Türk Pediatr Arşivi 2011;46(1):75-80.

18. Demir R, Özçırpıcı B. Bir sağlık ocağı bölgesinde yaşayan 0-2 yaş çocuklarda malnütrisyon sıklığı ve malnütrisyon saptanan çocukların annelerine verilen eğitimin etkisi. Çocuk Sağlığı ve Hast Derg 2014;57:183-90.

19. Yeşinel S, Aldemir EY, Kavuncuoğlu S, Yeşinel S, Yıldız H. Çok düşük doğum ağılıklı erken doğmuş bebeklerde büyümenin değerlendirilmesi. Türk Pediatr Ars 2014;49(4):289-98.

20. Sivri BB. 0-6 Aylık Bebeği Olan Annelerin Kat Gıdaya Geçiş Süreci ve Emzirmeye ilişkin Bilgi ve Uygulamaları. Acıbadem Üniversitesi Sağlık Bilim Derg 2014;5(1):59-65.

21. Çöl Araz N. Yenidoğan döneminde anne sütü ile beslenmeye başlanması üzerinde etkili olan sosyodemografik faktörlerin değerlendirilmesi. Türkiye Çocuk Hast Derg 2012;6(4):215-20.

22. Şanlıer N, Aytekin F. Ankara'da yaşayan 0-36 ay çocukların bazı antropometrik ölçümleri ve anne sütü ile beslenme durumlarının saptanması. GÜ, Gazi Eğitim Fakültesi Derg 2004;24(1):271-89. 
23. WHO. Maternal, infant and young child nutrition report by the secretariat. executive board. World Heal Organ 2013;4:1-10.

24. Nguyen PH, Menon P, Ruel M, Hajeebhoy N. A situational review of infant and young child feeding practices and interventions in viet nam. Asia Pac J Clin Nutr 2011;20(3):359-74.

25. Caetano MC, Ortiz TTO, Da Silva SG lopes, De Souza FIsS, Sarni ROS. Complementary feeding: Inappropriate practices in infants. Rev Chil Pediatr 2012;83(5):503.

26. İnanç N, Aykut $M$, Çiçek B, Şahin H, Yılmaz M, Katrancı D, et al. Kayseri II Merkezi'nde 0 - 36 Aylık çocuklarda malnütrisyon durumu ve etkileyen bazı faktörler. Türk Hij Den Biyol Derg 2005;62(1):41-8.

27. Jones-Smith JC, Neufeld LM, Laraia B, Ramakrishnan U, GarciaGuerra A, Fernald LCH. Early life growth trajectories and future risk for overweight. Nutr Diabetes 2013;3:60-7.

28. Patel V. Postnatal depression and infant growth and development in low income countries: a cohort study from Goa, India. Arch Dis Child 2003;88(1):34-7.

29. Caroli M, Mele RM, Tomaselli MA, Cammisa M, Longo F, Attolini E. Complementary feeding patterns in Europe with a special focus on Italy. Nutr Metab Cardiovasc Dis 2012;22(10):813-8.

30. Neyzi O, Günöz H, Furman A, Bundak R, Gökçay G, Darendeliler F, et al. Türk çocuklarinda vücut ağirliği, boy uzunluğu, baş çevresi ve vücut kitle indeksi referans değerleri. Cocuk Sagligi ve Hast Derg 2008;51(1):1-14.

31. Neyzi $O$, Ertuğtul T. Büyüme ve Gelişmenin değerlendirilmesi. In: Pediyatri. 2009. p. 1000.

32. European Food Safety Authority (EFSA). Scientific opinion on the appropriate age for introduction of complementary feeding of infants- EFSA Panel on Dietetic Products, Nutrition and Allergies (NDA). EFSA J 2009;7(12):1-38.
33. Aktaç Ş, Garipağaoğlu M, Gökçay G, Akman Z. Çocuk sağlığı izlem polikliniğinde takip edilen dokuz ve on iki aylık bebeklerde tamamlayıcı beslenme uygulamaları ve besin ögesi alımlarının belirlenmesi. Çocuk Derg 2015;15(2):56-64.

34. Yang Z, Huffman SL. Nutrition in pregnancy and early childhood and associations with obesity in developing countries. Matern Child Nutr 2013;9:105-19.

35. Ip EH, Marshall SA, Santiago S, Skelton JA, Suerken CK, Arcury TA, et al. Determinants of adiposity rebound timing in children. J Pediatr 2017;184:151-6.

36. Börnhorst $C$, Siani A, Tornaritis $M$, Molnár D, Lissner L, Regber $S$, et al. Potential selection effects when estimating associations between the infancy peak or adiposity rebound and later body mass index in children. Int J Obes 2017;41:518-26.

37. Agostoni C, Braegger C, Decsi T, Kolacek S, Koletzko B, Michaelsen $\mathrm{KF}$, et al. Complementary feeding: A commentary by the ESPGHAN Committee on Nutrition. J Pediatr Gastroenterol Nutr 2009;49(1):112-25.

38. Li R, Fein SB, Chen J, Grummer-Strawn LM. Why mothers stop breastfeeding: Mothers' self-reported reasons for stopping during the first year. Pediatrics 2008;122:69-76.

39. Conn JA, Davies MJ, Walker RB, Moore VM. Food and nutrient intakes of 9-month-old infants in Adelaide, Australia. Public Health Nutr 2009;12(12):2448-56.

40. Butte NF, Fox MK, Briefel RR, Siega-Riz AM, Dwyer JT, Deming DM, et al. Nutrient intakes of us infants, toddlers, and preschoolers meet or exceed dietary reference intakes. J Am Diet Assoc 2010;110(12):S27-37.

41. Boran $\mathrm{P}, \mathrm{Aktaç} \mathrm{Ş.} \mathrm{Diversity} \mathrm{and} \mathrm{nutrient} \mathrm{composition} \mathrm{of} \mathrm{the} \mathrm{diets}$ of breastfed infants. Turkiye Klinikleri J Pediatr 2018;27:9-19. 